\title{
Eco-Friendly Synthesis, TEM and Magnetic Properties of Co-Er Nano-Ferrites
}

\author{
Edapalli Sumalatha ${ }^{1}$, Maramu Nyathani ${ }^{2}$, T. Anil Babu ${ }^{3 \mathbb{D}}$, Dachepalli Ravinder ${ }^{1, *}{ }^{\mathbb{D}}$, N.V. Krishna \\ Prasad $^{3}$ (D), Sadhana Katlakunta ${ }^{2}$ \\ 1 Department of Physics, Osmania University, Hyderabad-500007, Telangana, India \\ 2 Department of Physics, University College of Science, Saifabad, Osmania University, Hyderabad-500004, Telangana, \\ India \\ 3 Department of Physics, GITAM Deemed to be University, Bengaluru, Karnataka-562163, India \\ * Correspondence: ravindergupta28@ rediffmail.com;
}

Scopus Author ID 57190787752

Received: 27.02.2021; Revised: 2.04.2021; Accepted: 6.04.2021; Published: 26.04.2021

\begin{abstract}
Synthesis of Cobalt-Erbium nano-ferrites with formulation $\mathrm{CoEr}_{\mathrm{x}} \mathrm{Fe}_{2-\mathrm{x}} \mathrm{O}_{4}(\mathrm{x}=0,0.005,0.010$, $0.015,0.020,0.025$, and 0.030 ) using technique of citrate-gel auto-combustion was done. Characterization of prepared powders was done using XRD, EDAX, FESEM, TEM, AFM, and FTIR spectroscopy, VSM: magnetic properties, respectively. XRD Rietveld Analysis, SEM, TEM, and EDAX analysis studied spectral, structural, and magnetic properties. XRD pattern of CEF nanoparticles confirms single-phase cubic spinal structure. The structural variables are given by lattice constant (a), lattice volume (v), the average crystallite size (D) and X-ray density $(d x)$, bulk density $(d)$, porosity $(\mathrm{p})$, percentage of pore space $(\mathrm{P} \%)$, surface area $(\mathrm{s}), \operatorname{strain}(\varepsilon)$, dislocation density $(\delta)$, along with ionic radii, bond length and hoping length were calculated. SEM and TEM results reveal the homogeneous nature of particles accompanied by clusters having no impurity pickup. TEM analysis gives information about the particle size of nanocrystalline ferrite, while EDAX analysis confirms elemental composition. The emergence of two arch-shaped frequency bands $\left(v_{1}\right.$ and $\left.v_{2}\right)$ that represent vibrations at the tetrahedral site (A) and octahedral site(B) was indicated by spectra of FTIR. The XRD Rietveld analysis confirms crystallite size lying between $20.84 \mathrm{~nm}-14.40 \mathrm{~nm}$, while SEM analysis indicates the formation of agglomerates and TEM analysis indicates particle size ranging between $24 \mathrm{~nm}-16 \mathrm{~nm}$. The XRD Rietveld analysis confirms crystallite size lying between $20.84 \mathrm{~nm}-14.40 \mathrm{~nm}$, while SEM analysis indicates the formation of agglomerates and TEM analysis indicates particle size ranging between 24 $\mathrm{nm}-16 \mathrm{~nm}$. The magnetization measurements indicated that increasing $\mathrm{Er}^{3+}$ content in cobalt ferrites decreases magnetization from 60emu/g to 42emu/g while coercivity decreases (18990) as compared to $\mathrm{CoFe}_{2} \mathrm{O}_{4}$ (18998) in cobalt ferrites with doping. The present study investigates the effect of different compositions of $\mathrm{Er}^{3+}$ replaced for $\mathrm{Fe}$ on structural and magnetic properties of cobalt ferrites.
\end{abstract}

Keywords: magnetic properties; Co-Er nano-particles; TEM; XRD; FESEM; EDAX; AFM.

(C) 2021 by the authors. This article is an open-access article distributed under the terms and conditions of the Creative Commons Attribution (CC BY) license (https://creativecommons.org/licenses/by/4.0/).

\section{Introduction}

Vigorous research has been accomplished on the fundamental, technological, and potential applications of nano-ferrites. Nanomaterials of spinel ferrite have several applications in technology that include magnetic diagnostics and drug delivery [1,2], potential applications that include high-density magnetic information storage devices [3], ferrofluid technology [4], magnetocaloric refrigeration [5], magnetic recording media, magnetostriction [6], magnetic sensors, microwave devices [7], electrical generators, etc. Ferrites are also used for catalysts 
and electronic devices. Ferrites exhibit various magnetic and electric properties such as low electrical conductivity, dielectric loss, magnetic loss, relative loss factor, moderate dielectric constant, high initial permeability, and saturation magnetization. Low eddy current and high resistivity make ferrites a better choice than metals [8]. Doping and thermal changes during synthesis and processing of cobalt-ferrites alter the distribution of metal ions influencing their structure and magnetic properties [9]. As per the literature net magnetic moment of lanthanide series elements/ions depend on the f-orbital electron number in which $\mathrm{Er}^{+3}$ is of small size (89 $\mathrm{pm})$ with a large magnetic moment $(7 \mu \mathrm{B})$ [10]. If doped, magnetic anisotropy of cobalt ferrites is influenced by the existence of $\mathrm{Er}^{+3}$ because of strength in spin-orbit coupling. The present work reports the preparation and characterization of erbium-doped cobalt ferrites combined by Citrate-gel auto combustion. The studies of $\mathrm{CoEr}_{x} \mathrm{Fe}_{2-\mathrm{x}} \mathrm{O}_{4}$ with cobalt content $\mathrm{x}$ values ranging between 0.000 to 0.030 with a step increase of $x=0.005$ were reported. The crystallite size decreases with increasing erbium content indicates an increase in the particle's surface area, making it a good adsorbent [11]. These adsorbents can be used in gas sensors and wastewater treatment, etc.

\section{Materials and Methods}

Synthesis of Cobalt-Erbium nano-ferrites with citrate-gel auto combustion technique was taken up with starting materials Cobalt Nitrate $\left(\mathrm{Co}\left(\mathrm{NO}_{3}\right)_{2} \cdot 6 \mathrm{H}_{2} \mathrm{O}\right)$, Ferric nitrate $\left(\mathrm{Fe}\left(\mathrm{NO}_{3}\right)_{3} \cdot 9 \mathrm{H}_{2} \mathrm{O}\right)$, Erbium Nitrate $\left(\mathrm{Er}\left(\mathrm{NO}_{3}\right) \cdot 6 \mathrm{H}_{2} \mathrm{O}\right)$, Citric Acid $\left(\mathrm{C}_{6} \mathrm{H}_{8} \mathrm{O}_{7} \cdot \mathrm{H}_{2} \mathrm{O}\right)$ and Ammonia solution $\left(\mathrm{NH}_{3}\right)$ of $99.9 \%$ purity after weighing as per stoichiometric ratio. Later liquefication of metal nitrates in distilled water was done, and the mixture was stirred at $300 \mathrm{rpm}$ for one hour to obtain a clear homogeneous solution.

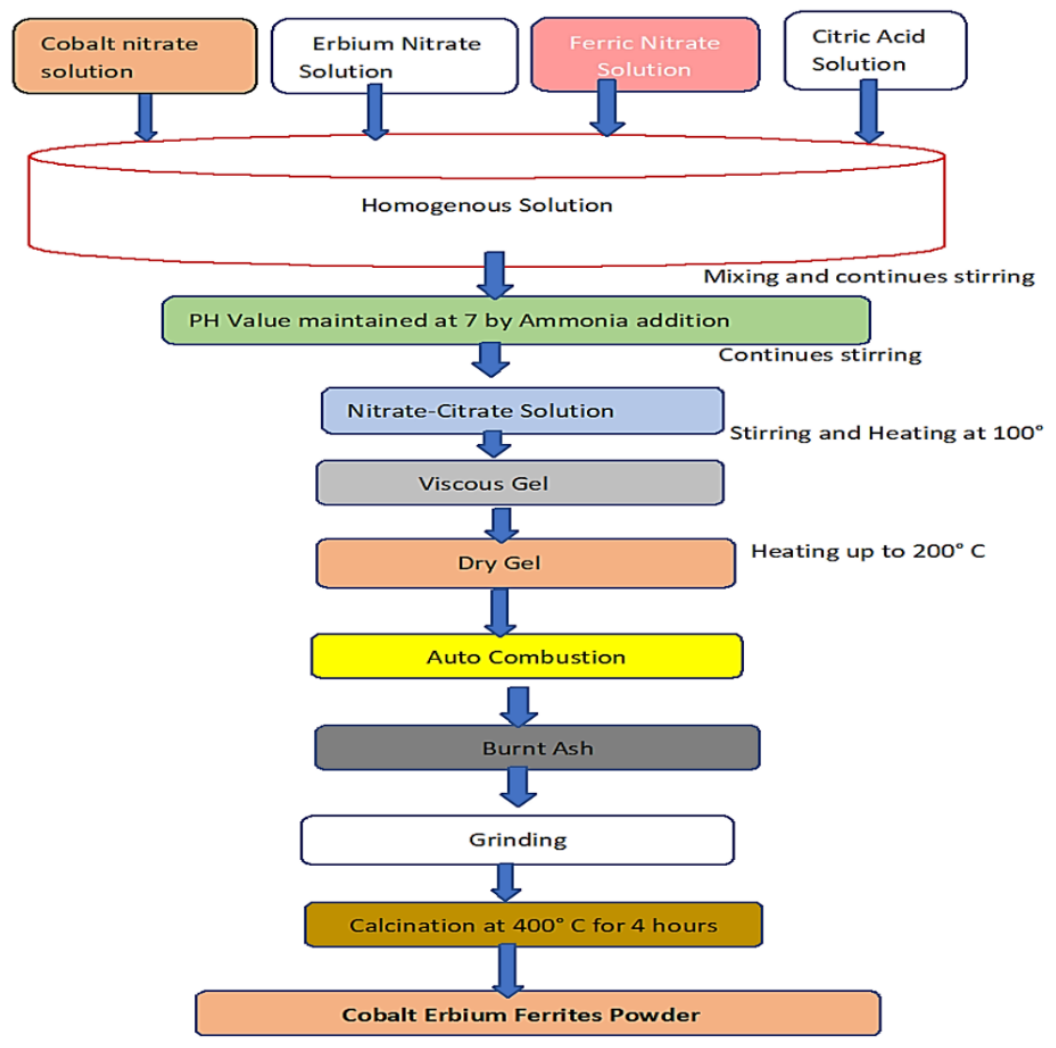

Figure 1. Flow chart of synthesis of Cobalt-Erbium Ferrite.

Next citric acid in aqueous form and metal nitrate was maintained in a 1:3 ratio for all samples. Now, ammonia solution was added drop by drop to maintain $\mathrm{pH}=7$. This solution on 
stirring was heated at $100{ }^{\circ} \mathrm{C}$ temperature for ten to twelve hours to form a viscous gel. The water contained in the mixture gets evaporated slowly to form dry gel generating internal combustion to form a black-colored desired sample. This sample was manually ground and subjected to calcination at $500{ }^{\circ} \mathrm{C}$ in the furnace for 4 hours. Later these samples in pellet or powder form undergo characterizations with XRD (Bruker, $\mathrm{Cu} \mathrm{K} \alpha, \lambda=0.15406 \mathrm{~nm}$ ), TEM (Model JEOL 2100F, Japan), and Field-emission Scanning Electron Microscope (JEOL JSM7600 F, Japan) with Energy Dispersive X-ray Analyzer (EDAX) for structural, Atomic Force Microscopy (AFM:VEECO, USA), VSM: magnetic properties respectively (Figure 1).

\section{Results and Discussion}

\subsection{Analysis of XRD.}

Figure 2(a-g) displays the XRD Rietveld Refinements corresponding to samples of $\mathrm{CoEr}_{\mathrm{x}} \mathrm{Fe}_{2-\mathrm{x}} \mathrm{O}_{4}$ with values of $\mathrm{x}$ between 0.00 to 0.030 ( $\mathrm{x}=$ incremented by 0.005 ). In Figure 4 it is observed that the peaks analogous to diffraction planes [111], [320], [311], [400], [511] and [440] match with usual data (JCPDS card no. 022-1086) confirming FCC cubic spinel structure for samples investigated [12-14]. Figure 4 shows a shift in XRD peaks towards the left-hand side with increasing concentration of $\mathrm{Er}^{+3}$ ions in $\mathrm{CoFe}_{2} \mathrm{O}_{4}$ particles in concurrence with 'a' value. Table 1. lists different parameters of XRD calculated for $\mathrm{CoEr}_{\mathrm{x}} \mathrm{Fe}_{2}-\mathrm{x} \mathrm{O}_{4}$ nanoparticles. The values of 'a' were calculated from the below equation-1 [15].

$$
\mathrm{a}=\mathrm{d} *\left(\mathrm{~h}^{2}+\mathrm{k}^{2}+\mathrm{l}^{2}\right)^{1 / 2}
$$

where cell constant is given by 'a', inter planer spacing calculated from Bragg's equation $(2 \mathrm{~d} \sin \theta=n \lambda)$ is denoted by 'd', and miller indices are done by ' $h, k, l$ '.

Table 1. The calculated values of Ionic Radii's are listed below.

\begin{tabular}{c|c|c|c} 
Compositions & Lattice constant & \multicolumn{2}{c}{ Ionic radii $(\AA)$} \\
\hline $\mathrm{CoFe}_{2} \mathrm{O}_{4}$ & $\mathrm{~A}$ & $\mathrm{r}_{\mathrm{A}}$ & $\mathrm{r}$ \\
\hline $\mathrm{CoEr}_{0.005} \mathrm{Fe}_{1.995} \mathrm{O}_{4}$ & 8.361 & 0.5760 & 0.6733 \\
\hline $\mathrm{CoEr}_{0.010} \mathrm{Fe}_{1.990} \mathrm{O}_{4}$ & 8.367 & 0.5773 & 0.6748 \\
\hline $\mathrm{CoEr}_{0.015} \mathrm{Fe}_{1.985} \mathrm{O}_{4}$ & 8.373 & 0.5787 & 0.6762 \\
\hline $\mathrm{CoEr}_{0.020} \mathrm{Fe}_{1.980} \mathrm{O}_{4}$ & 8.379 & 0.5801 & 0.6777 \\
\hline $\mathrm{CoEr}_{0.025} \mathrm{Fe}_{1.975} \mathrm{O}_{4}$ & 8.386 & 0.5817 & 0.6794 \\
\hline $\mathrm{CoEr}_{0.030} \mathrm{Fe}_{1.970} \mathrm{O}_{4}$ & 8.392 & 0.5831 & 0.6808 \\
\hline
\end{tabular}

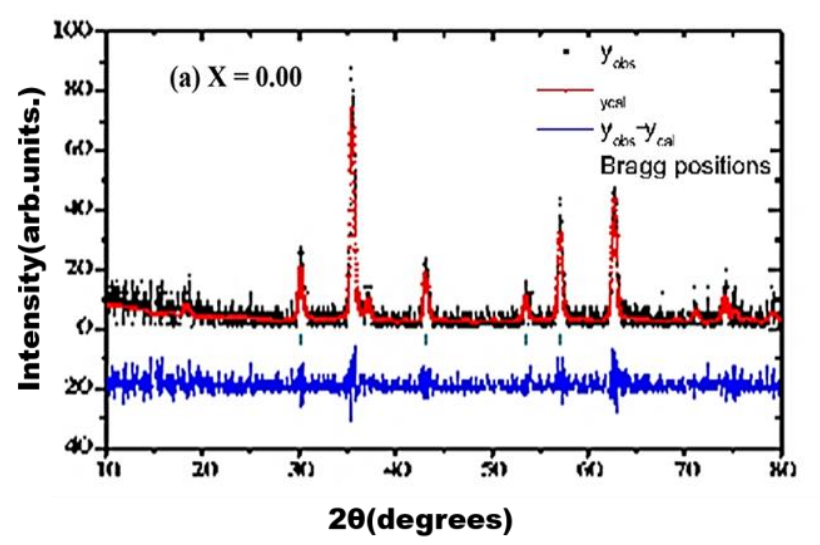



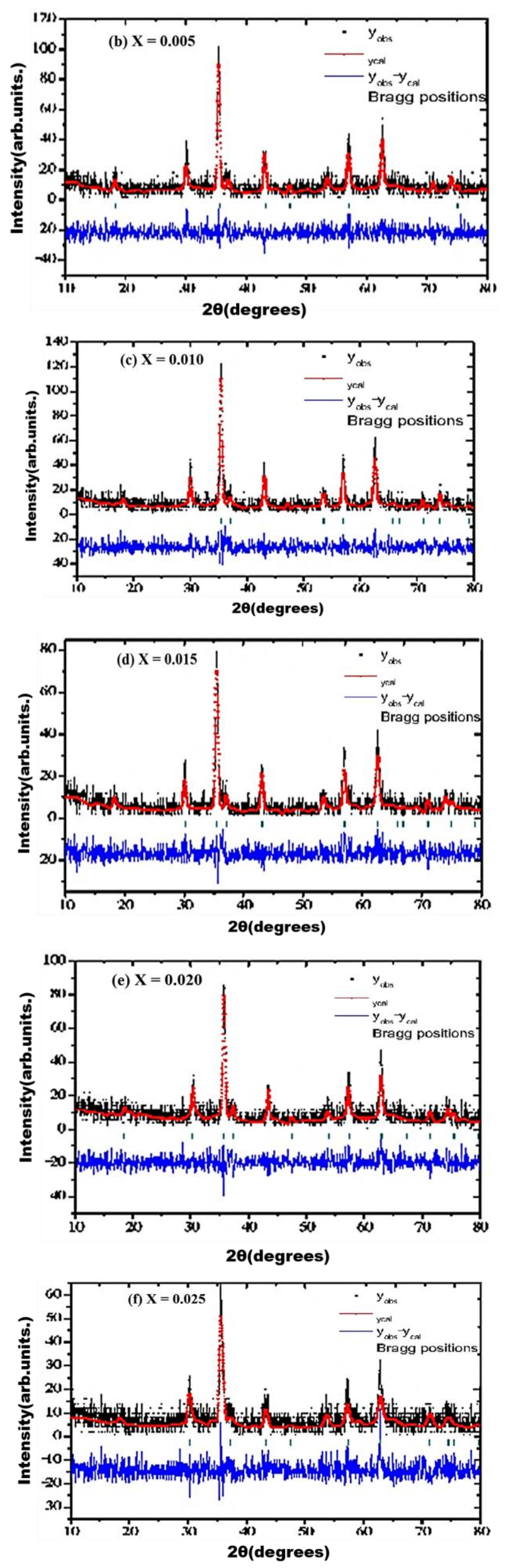


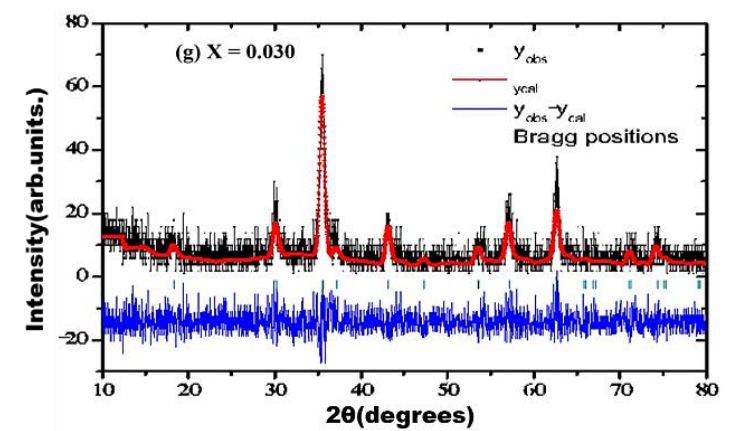

Figure 2(a-g). XRD Rietveld refinement patterns of $\mathrm{CoEr}_{x} \mathrm{Fe}_{2-\mathrm{x}} \mathrm{O}_{4}$ ferrites with $\mathrm{x}=0.00-0.030$.

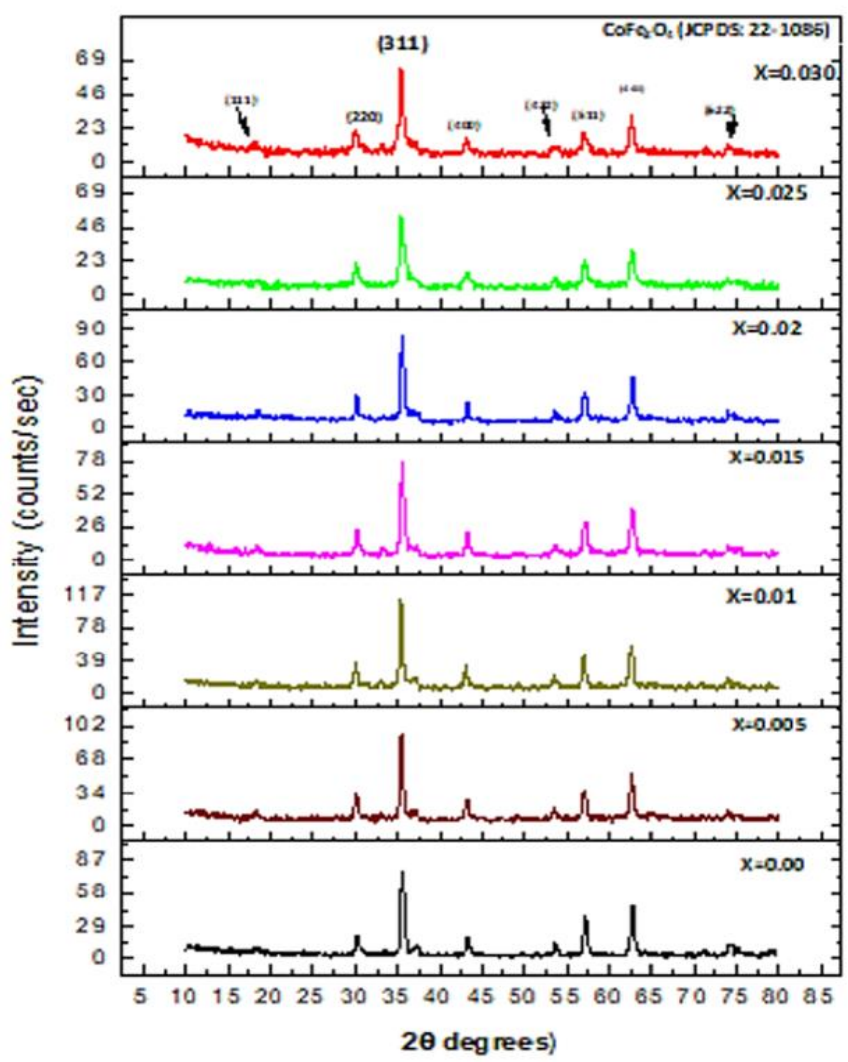

Figure 3. $\mathrm{XRD}$ patterns of the " $\mathrm{CoEr}_{\mathrm{x}} \mathrm{Fe}_{2-\mathrm{x}} \mathrm{O}_{4}$ " nano ferrites $(0.00 \leq \mathrm{x} \leq 0.030)$.

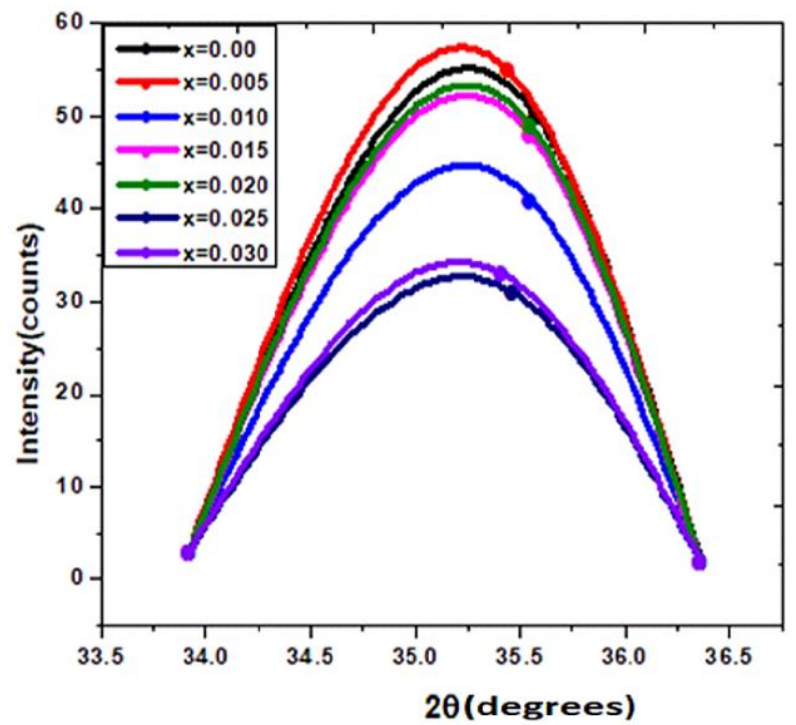

Figure 4. The shifting of peaks from XRD patterns of $\mathrm{CoEr}_{x} \mathrm{Fe}_{2-\mathrm{x}} \mathrm{O}_{4}(0.00 \leq \mathrm{x} \leq 0.030)$ nano ferrites. 
It was reported that low concentration RE (rare earth) doping in spinel ferrite experiences phase separation and grain boundary diffusion, giving rise to precipitation of additional crystalline phases like hematite $\left(\mathrm{a}-\mathrm{Fe}_{2} \mathrm{O}_{3}\right)$, metal monoxides, and orthoferrites $\left(\mathrm{REFeO}_{3}\right)$ [16-18]. Hence, in rare-earth-doped ferrites, $\mathrm{Er}^{+3}$ doped $\mathrm{CFO}$ having no impurity phase $(x \leq 0.010)$ is exceptional and is because of auto-combustion. The induced effect due to the substitution of erbium on the structure reflects two main observations: the decrease in crystal size and the increase in lattice constant on a small scale. The lattice value constant slightly enhanced between $8.361 \AA$ to $8.398 \AA$ for $x=0.000$ to $x=0.030$ as per the Law of Vegard [19]. Scherrer formula [20] was used to calculate the crystallite size given by:

$$
\mathrm{L}=\frac{0.9 * \lambda}{\beta \cos \theta}
$$

where ' $\lambda$ ' = wavelength of $x$-ray,' $\beta$ ' = peak width at half maximum height, and constant ' $K$ ' = 0.9. The data relating to intense peak (311) was used in estimating size (L). The results indicated a reduction in crystallite size from $20.84 \mathrm{~nm}$ to $14.40 \mathrm{~nm}$ (for $\mathrm{x}=0.0$ to 0.030 ). Further, the intense high peak (311) shifts towards the lower angle [21] with increasing values of $x$ (Figure 4). Table 1 lists the physical parameters obtained from XRD, which indicated an increase in lattice constant [22] of Co-Fe-Er spinel lattice, which might be due to the replacement of 8 small $\mathrm{Co}^{2+}$ and $\mathrm{Fe}^{3+}$ ions with big $\mathrm{Er}^{3+}$ ions. Huge differences in radii of these three ions induce strain during the formation of lattice and diffusion processes. The requirement of more energy in absorbing $\mathrm{RE}^{3+}$ ions with more radii while replacing $\mathrm{Fe}^{3+}$ to form $\mathrm{RE}-\mathrm{O}$ bond decreases crystallization energy and leads to small size particles. Earlier literature reported similar results on RE-ion substituted cobalt ferrite [23-26]. From Table 2. EDAX confirmed the effect of incorporating $\mathrm{Er}^{3+}$ into $\mathrm{CFO}$ and a stoichiometric amount of $\mathrm{O}, \mathrm{Fe}, \mathrm{Co}$, and $\mathrm{Er}$ atoms. Therefore, $\mathrm{XRD}$ results are liable for expansion of unit cell due to larger $\mathrm{Er}^{3+}$ ion doping in CFO. Calculation of X-ray density (Dx) [27] was done using:

$$
\mathrm{d}_{\mathrm{x}}=\frac{8 * M}{N a 3}
$$

Here

' $M$ ' = compositionmolecular weight

' $N$ '= Avogadro's number

' $a$ '= lattice constant.

Table 2. The atomic weight of $\mathrm{CoEr}_{\mathrm{x}} \mathrm{Fe}_{2-\mathrm{x}} \mathrm{O}_{4}$ ferrite nanoparticles are measured from EDAX.

\begin{tabular}{c|c|c|c|c} 
Composition $(\mathbf{x})$ & Co & Fe & Er & O \\
\hline$X=0.000$ & 12.40 & 34.43 & 0.000 & 26.86 \\
\hline$X=0.005$ & 12.37 & 34.27 & 0.094 & 26.80 \\
\hline$X=0.010$ & 12.34 & 34.10 & 0.18 & 26.74 \\
\hline$X=0.015$ & 12.31 & 33.93 & 0.28 & 26.67 \\
\hline$X=0.020$ & 12.28 & 33.77 & 0.37 & 26.61 \\
\hline$X=0.025$ & 12.25 & 33.60 & 0.46 & 26.55 \\
\hline$X=0.030$ & 12.23 & 33.44 & 0.55 & 26.49
\end{tabular}

$\mathrm{X}$-ray density value is found to increase from $5.3344 \mathrm{gm} / \mathrm{cm} 3$ to $5.3392 \mathrm{gm} / \mathrm{cm} 3(x=$ 0.00 to $x=0.030$ ) with increasing $\mathrm{Er}^{3+}$ content. The bulk density increased from 3.2113 to 3.2141 ( $\mathrm{x}=0.00$ to $\mathrm{x}=0.030$ ). At the same time, $\mathrm{CoFe}_{2-\mathrm{x}} \mathrm{Er}_{\mathrm{x}} \mathrm{O}_{4}$ ceramics having more Er content $(\mathrm{x}=0.015)$ exhibited lower $\mathrm{ErFeO}_{3}$ orthoferrite amount along with primary spinel ferrite phase. Cobalt ferrite in inverse spinel form has a tetrahedral site occupied by half of $\mathrm{Fe}^{+3}$. In contrast, the remaining half of $\mathrm{Fe}^{+3}$ and $\mathrm{Co}^{-2}$ occupy octahedral sites [29]. Any change in site occupation 
of $\mathrm{Fe}^{+3}$ and $\mathrm{Co}^{-2}$ might be because of preparation technique and affect cell constant. Bulk densities were found from the relation [29]:

$$
\mathrm{d}=\frac{m}{\pi r 2 h}
$$

where pellets mass, thickness and radius are given by ' $m$ ',' $h$ 'and ' $r$ '. Bulk densities exhibit inhomogeneous behavior due to pallets' variable thickness and mass. The values of porosity in percentage were found using the relation.

$$
\mathrm{P} \%=\left(1-\mathrm{d} / \mathrm{d}_{\mathrm{x}}\right) \times 100
$$

Here $\mathrm{d}$ and $\mathrm{d}_{\mathrm{x}}$ are apparent and experimental densities. The surface area was calculated by using the equation [20]:

$$
\mathrm{S}=\frac{6000}{D * d}
$$

Here, $\mathrm{S}=$ area of surface, $\mathrm{D}=$ crystallite size, $\mathrm{d}=$ bulk density

The strain was calculated by using the following equation [30].

$$
\operatorname{Strain}(\varepsilon)=1 / D^{\wedge} 2
$$

Here, $d$ is the inter planer spacing. Dislocation density calculated by using the following equation:

$$
\text { Dislocation density }(\delta)=15 \varepsilon / a D
$$

Here $\varepsilon$ is the strain, a is lattice constant, D is crystallite size. The packing factor is calculated by using the following equation

$$
\mathrm{P}=\frac{\text { Lnm }}{d}
$$

Here $\mathrm{L}$ is crystallite size, $\mathrm{d}$ is inter planner spacing.

Cationic distributions that depend on the synthesis, total energy, and thermal history help understand spinel ferrites' behavior (electric and magnetic). Cationic calculations play an important role in this regard. Average ionic radii [31] of A, B sites were calculated from Stanley's equations:

$$
\begin{gathered}
r_{A}=[u-1 / 4] a \times(3)^{0.5}-R_{O} \\
r_{B}=(5 / 8-u) a-R_{O}
\end{gathered}
$$

Here $\mathrm{R}_{\mathrm{o}}$ is the radius of the oxygen ion $\left(1.35 A^{0}\right)$, 'u' is the oxygen parameter whose ideal value is $0.375 A^{0}$ and experimental value is $0.383 A^{0}$.

Bonding lengths and hopping lengths are calculated by using the following formulas [32]:

Bonding lengths:

$$
\begin{aligned}
& d_{A-A}=\frac{a}{4} \times(3)^{0.5}(12) \\
& d_{B-B}=\frac{a}{4} \times(2)^{0.5} a \\
& d_{A-B}=\frac{a}{8} \times(11)^{0.5} \\
& d_{A-O A}=a\left(u-\frac{1}{4}\right) *(3)^{0.5}
\end{aligned}
$$

Hoping lengths:

$$
\begin{aligned}
& \mathrm{L}_{\mathrm{A}}=\frac{\sqrt{3}}{4} \times a \\
& \mathrm{~L}_{\mathrm{B}}=\frac{\sqrt{2}}{4} \times a
\end{aligned}
$$


$\mathrm{d}_{\mathrm{B}-\mathrm{OB}}=\mathrm{a}\left\{2(\mathrm{u}-3 / 8)^{2}+(5 / 8-\mathrm{u})^{2}\right\}^{0.5}$

Table 3. The calculated values of Hoping lengths are listed below.

\begin{tabular}{c|c|c|c} 
Compositions & Lattice constant & \multicolumn{2}{|c}{ Hoping lengths $(\AA)$} \\
\hline & $\mathrm{A}$ & 3.6203 & LB \\
\hline $\mathrm{CoFe}_{2} \mathrm{O}_{4}$ & 8.361 & 3.6229 & 2.9556 \\
\hline $\mathrm{CoEr}_{0.005} \mathrm{Fe}_{1.995} \mathrm{O}_{4}$ & 8.367 & 3.6255 & 2.9577 \\
\hline $\mathrm{CoEr}_{0.010} \mathrm{Fe}_{1.990} \mathrm{O}_{4}$ & 8.373 & 3.6281 & 2.9598 \\
\hline $\mathrm{CoEr}_{0.015} \mathrm{Fe}_{1.985} \mathrm{O}_{4}$ & 8.379 & 3.6311 & 2.9619 \\
\hline $\mathrm{CoEr}_{0.020} \mathrm{Fe}_{1.980} \mathrm{O}_{4}$ & 8.386 & 3.6337 & 2.9644 \\
\hline $\mathrm{CoEr}_{0.025} \mathrm{Fe}_{1.975} \mathrm{O}_{4}$ & 8.392 & 3.6363 & 2.9686
\end{tabular}

The difference in ' $u$ ' value compared to its ideal value on substituting $\mathrm{Er}^{+3}$ ions has been explained with $r_{A}$ values. Increasing $r_{A}$ values increase ' $u$ ', showing distortion in $\mathrm{CoFe}_{2} \mathrm{O}_{4}$ spinel lattice. Calculated ionic radii values for B-sites are slightly higher than A-site because more $\mathrm{Er}^{+3}$ ions reside at B-site than A-site. Hopping length is the gap between magnetic ions at A, B sites. The hopping lengths between magnetic ions at A, B sites are denoted by $\mathrm{L}_{\mathrm{A}}$ and LB whose values reduce with the addition of $\mathrm{Er}^{+3}$ content and are consistent with variation in lattice constant on adding $\mathrm{Er}^{+3}$ ions [33]. The determined values from the formulas $(10,11,17,18)$ are listed in Tables 1, 3, 4.

Table 4. Structural parameters of the prepared Co-Er nano ferrite sample.

\begin{tabular}{|c|c|c|c|c|c|c|c|c|c|c|}
\hline Compositions & $\begin{array}{l}\text { Cell } \\
\text { constant } \\
(\AA)\end{array}$ & $\begin{array}{l}\text { Cell } \\
\text { Volume } \\
\text { V }\left(\AA^{3}\right)\end{array}$ & $\begin{array}{l}\text { Crystalli } \\
\text { te Size } \\
(\mathbf{n m})\end{array}$ & $\begin{array}{l}\text { X-ray } \\
\text { density } \\
(\boldsymbol{d x}) \\
\left(\mathrm{gcm}^{-3}\right)\end{array}$ & $\begin{array}{l}\text { Bulk } \\
\text { density }(d) \\
\left(\mathrm{gcm}^{-3}\right)\end{array}$ & $\begin{array}{l}\text { Porosity } \\
\text { P(\%) }\end{array}$ & $\begin{array}{l}\text { Surface } \\
\text { area(s) } \\
\left(\mathbf{m}^{2} / \mathbf{g m}\right)\end{array}$ & $\begin{array}{l}\text { Pack } \\
\text { ing } \\
\text { facto } \\
\mathbf{r}(\mathbf{P})\end{array}$ & $\begin{array}{l}\text { Str } \\
\text { ain } \\
(\varepsilon) \mathbf{x} \\
10^{-3}\end{array}$ & $\begin{array}{l}\text { Dis } \\
\text { loca } \\
\text { tion } \\
\text { dens } \\
\text { ity } \\
(\boldsymbol{\delta}) \mathbf{x} \\
\mathbf{1 0}^{-4} \\
\end{array}$ \\
\hline $\mathrm{CoFe}_{2} \mathrm{O}_{4}$ & 8.361 & 584.48 & 20.84 & 5.3344 & 3.2113 & 39.8001 & 89.61 & 8.26 & 2.3 & 1.9 \\
\hline $\mathrm{CoEr}_{0.005} \mathrm{Fe}_{1.995} \mathrm{O}_{4}$ & 8.367 & 585.74 & 20.43 & 5.3356 & 3.2120 & 39.8005 & 91.39 & 8.09 & 2.3 & 2.0 \\
\hline $\mathrm{CoEr}_{0.010} \mathrm{Fe}_{1.990} \mathrm{O}_{4}$ & 8.373 & 587.00 & 19.19 & 5.3367 & 3.2127 & 39.7998 & 97.34 & 7.60 & 2.7 & 2.5 \\
\hline $\mathrm{CoE}_{0.015} \mathrm{Fe}_{1.985} \mathrm{O}_{4}$ & 8.379 & 588.26 & 19.02 & 5.3379 & 3.2134 & 39.8003 & 98.18 & 7.52 & 2.7 & 2.5 \\
\hline $\mathrm{CoEr}_{0.020} \mathrm{Fe}_{1.980} \mathrm{O}_{4}$ & 8.386 & 589.74 & 17.73 & 5.3370 & 3.2129 & 39.7995 & 105.38 & 7.01 & 3.1 & 3.2 \\
\hline $\mathrm{CoEr}_{0.025} \mathrm{Fe}_{1.975} \mathrm{O}_{4}$ & 8.392 & 591.01 & 15.56 & 5.3381 & 3.2135 & 39.8006 & 119.99 & 6.14 & 4.1 & 4.7 \\
\hline $\mathrm{CoEr}_{0.030} \mathrm{Fe}_{1.970} \mathrm{O}_{4}$ & 8.398 & 592.28 & 14.40 & 5.3392 & 3.2141 & 39.8018 & 132.58 & 5.68 & 4.8 & 5.9 \\
\hline
\end{tabular}

By using the relations below, structural parameters associated with $\mathrm{A}, \mathrm{B}$ sites are calculated. Magnetic interactions and their strengths among AA, BB and AB sites mainly depend on bond length and bond angle between positive and negative ions. An increase in bond angle increases magnetic interaction strength, while it reduces with increasing bond length as the strength has a direct relation with bond angle and inverse relation with bond length. Table 5 summarizes different bond lengths of $\mathrm{A}, \mathrm{B}$ sites ( $\mathrm{d}_{\mathrm{A}-\mathrm{A}}, \mathrm{d}_{\mathrm{B}-\mathrm{B}}, \mathrm{d}_{\mathrm{A}-\mathrm{B}}, \mathrm{d}_{\mathrm{A}-\mathrm{OA}}, \mathrm{d}_{\mathrm{B}-\mathrm{OB}}$ ) which depict an increase in bond lengths of tetrahedral and octahedral sites, which is due to $\mathrm{Er}^{+3}$ ion doping in spinel lattice, which might be due to larger $\mathrm{Er}^{+3}$ ions replacing smaller $\mathrm{Fe}^{+3}$ ions.

Table 5. The calculated values of bonding lengths are listed below.

\begin{tabular}{c|c|c|c|c|c} 
Composition & $\mathrm{d}_{\mathrm{A}-\mathrm{A}}$ & $\mathrm{dB}-\mathrm{B}$ & $\mathrm{d}_{\mathrm{A}-\mathrm{B}}$ & $\mathrm{d}_{\mathrm{A}-\mathrm{oA}}$ & $\mathrm{d}_{\mathrm{B}-\mathrm{OB}}$ \\
\hline $\mathrm{CoFe}_{2} \mathrm{O}_{4}$ & 3.620 & 2.956 & 3.466 & 1.926 & 2.025 \\
\hline $\mathrm{CoEr}_{0.005} \mathrm{Fe}_{1.995} \mathrm{O}_{4}$ & 3.622 & 2.958 & 3.468 & 1.927 & 2.026 \\
\hline $\mathrm{CoEr}_{0.010} \mathrm{Fe}_{1.990} \mathrm{O}_{4}$ & 3.625 & 2.960 & 3.471 & 1.928 & 2.027 \\
\hline $\mathrm{CoEr}_{0.015} \mathrm{Fe}_{1.985} \mathrm{O}_{4}$ & 3.628 & 2.962 & 3.473 & 1.930 & 2.029 \\
\hline $\mathrm{CoEr}_{0.020} \mathrm{Fe}_{1.980} \mathrm{O}_{4}$ & 3.631 & 2.964 & 3.476 & 1.931 & 2.031 \\
\hline $\mathrm{CoEr}_{0.025} \mathrm{Fe}_{1.975} \mathrm{O}_{4}$ & 3.633 & 2.966 & 3.479 & 1.933 & 2.032 \\
\hline $\mathrm{CoEr}_{0.030} \mathrm{Fe}_{1.970} \mathrm{O}_{4}$ & 3.636 & 2.969 & 3.481 & 1.934 & 2.033
\end{tabular}




\subsection{EDAX analysis.}

Figure 5(a-g) displays the EDAX spectrums that analyzed elemental and atomic percentages of $\mathrm{CoFe}_{2-\mathrm{x}} \mathrm{Er}_{\mathrm{x}} \mathrm{O}_{4}$ nanoparticles for $\mathrm{x}=0.0,0.005,0.010,0.015,0.020,0.025$ and 0.030. It confirmed the presence of $\mathrm{Co}, \mathrm{O}, \mathrm{Fe}$ and Er. Er peak confirms Erbium substitution in the $\mathrm{Fe}_{2-\mathrm{x}}$ lattice.
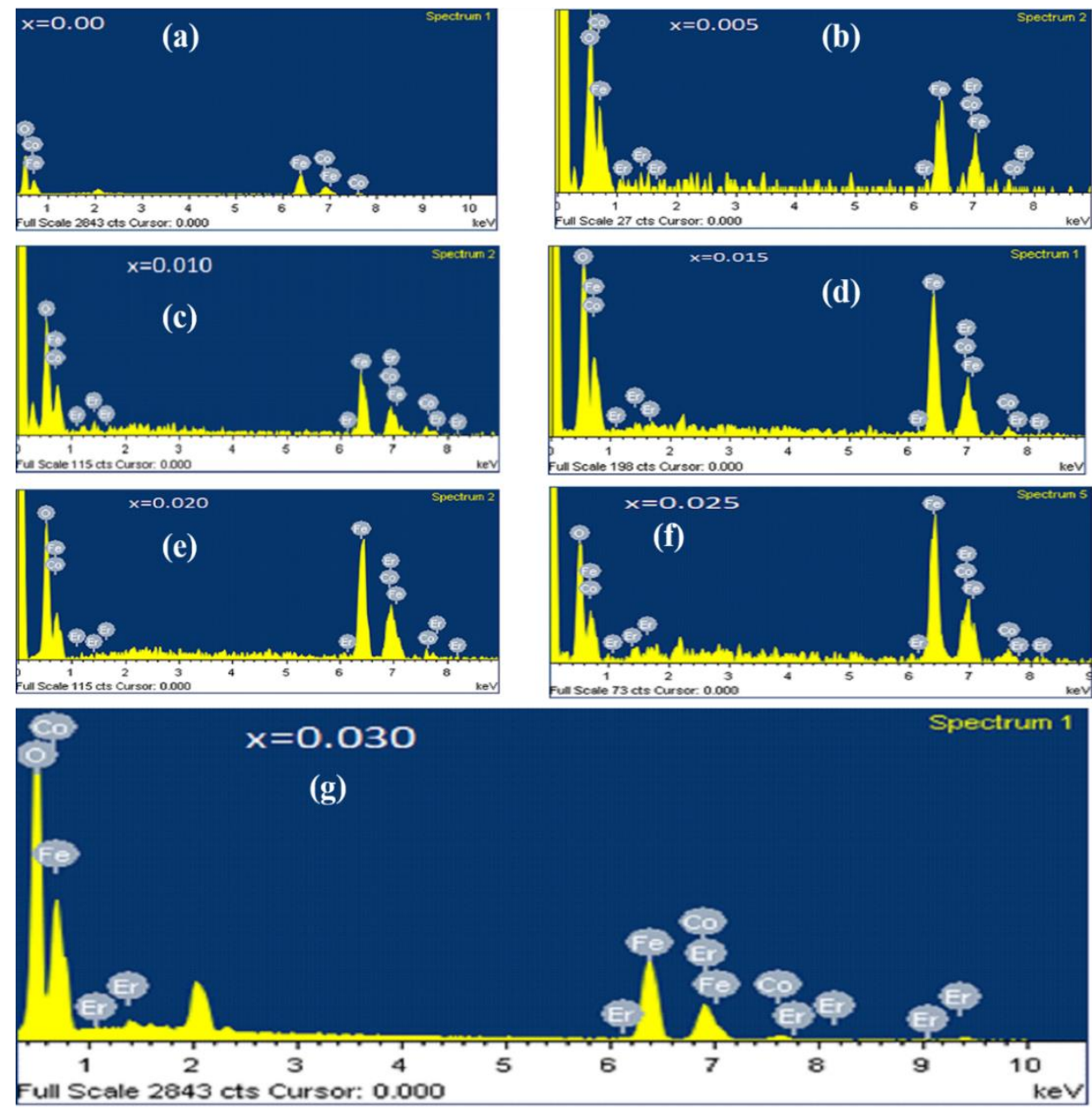

Figure 5(a-g). EDAX micrographs of $\mathrm{CoEr}_{x} \mathrm{Fe}_{2-\mathrm{x}} \mathrm{O} 4$ nano ferrites ( $\mathrm{x}$ in increasing order from 0 to 0.030 respectively from (a)-(g)).

\subsection{Field emission scanning electron microscopy (FE-SEM).}

Figure 6 shows studies on the surface morphology of ferrite powders with the help of FE-SEM. The nature of ferrite particles in the samples is uniform, indicating a fine form of agglomeration and grain growth. Agglomerate formation specifies the strong magnetic nature of erbium-doped ferrites. These studies also confirm microstructure changes on doping $\mathrm{Er}^{+3}$.

A close look at these microstructures indicates an improvement in microstructure and spherical-shaped grains in all samples. Apart from this, Erbium doping increases porosity percentage in a small range between 39.8001 to 39.8018 , illustrating that individual grains and grain boundaries are separated.

\subsection{AFM analysis.}

Atomic force microscopy (AFM) was used to characterize the surface roughness of $\mathrm{CoEr}_{\mathrm{x}} \mathrm{Fe}_{2-\mathrm{x}} \mathrm{O}_{4}$ nano ferrite samples of the synthesized nanoparticles. The three-dimensional arrangement of the spherical nanoparticles and their diameter is shown in Figure 7. 

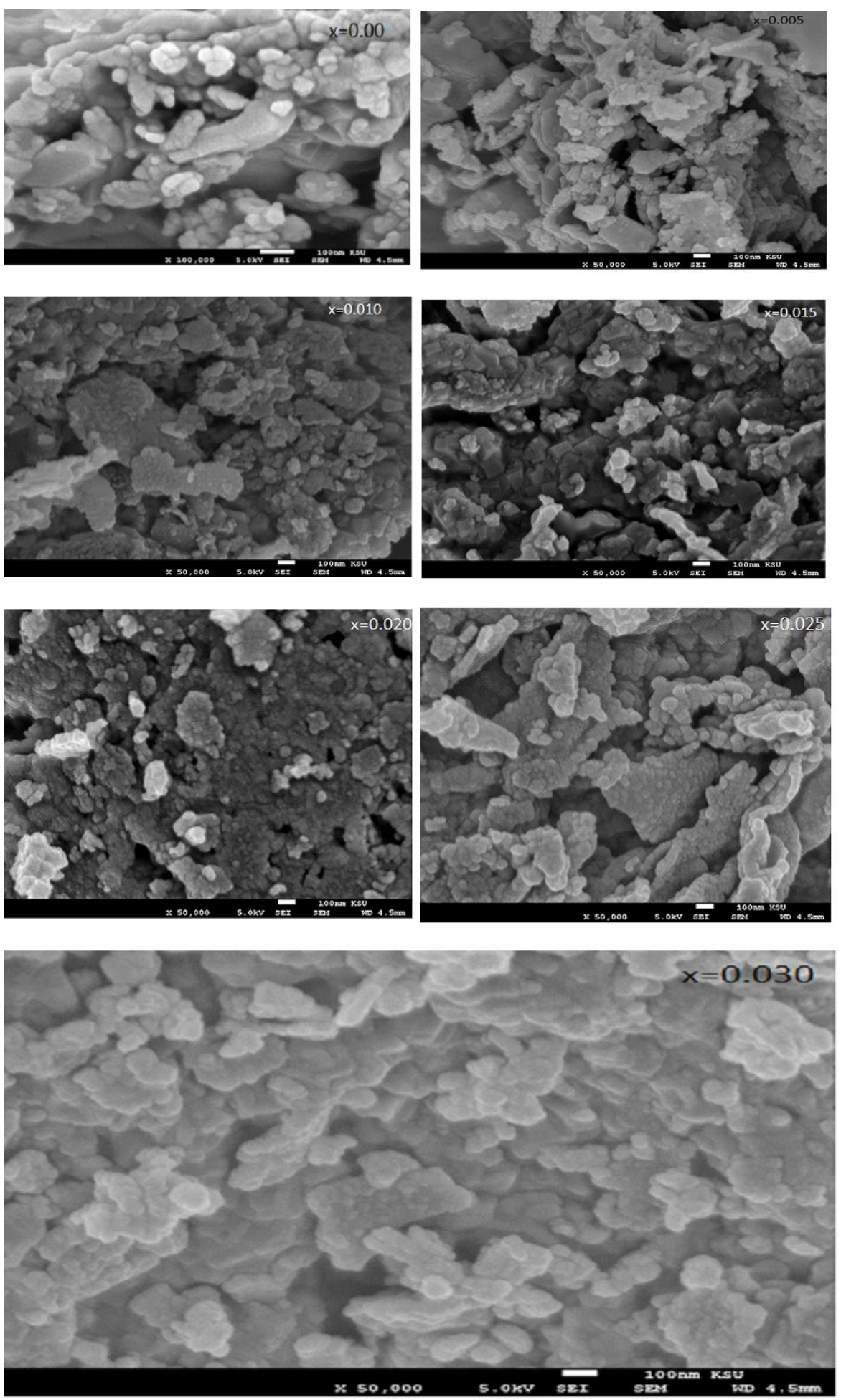

Figure 6. FE-SEM images of $\mathrm{CoEr}_{\mathrm{x}} \mathrm{Fe}_{2-\mathrm{x}} \mathrm{O} 4$ ferrites samples.

The surface roughness increased when the coercivity increases, but in this work, all the other parameters, such as crystallite size, saturation magnetization, remanent magnetization, coercivity, decreased with the increase of Er dopant from $x=0.00$ to 0.030 in the cobalt ferrite. Given the above, the largest surface roughness is observed for $x=0.0$ sample, and the lowest surface roughness is obtained for $\operatorname{Er}(\mathrm{x}=0.030)$ doped samples. This indicates that the surface activity of $x=0.0$ ferrite has higher values compared to the range $x=0.005-0.030$ ferrite samples. The largest surface roughness is observed for $\mathrm{x}=0.0$ sample; that is, it behaves like hard ferrite, and the lowest surface roughness is obtained for $\operatorname{Er}(\mathrm{x}=0.030)$ doped samples. It 
behaves like soft ferrite; thus, the ferrite is transformed from hard ferrite to soft ferrite due to the doping of Er content.
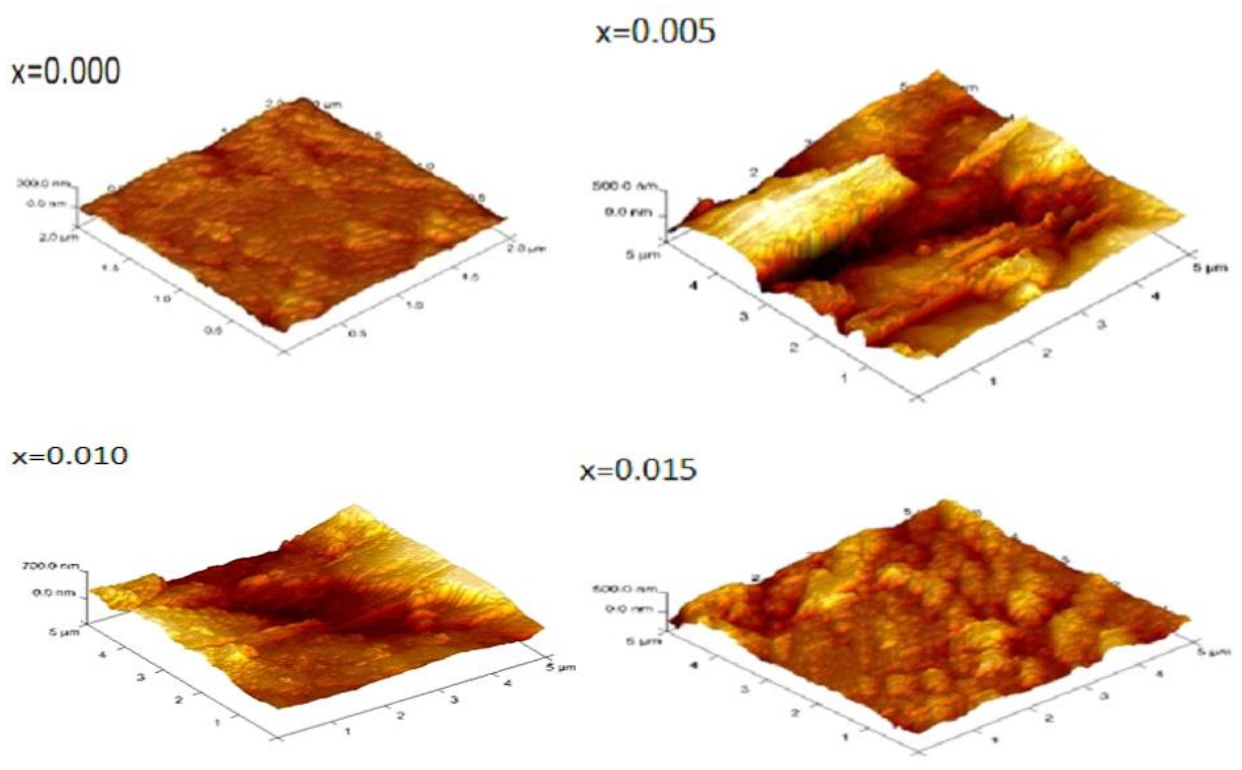

$x=0.025$
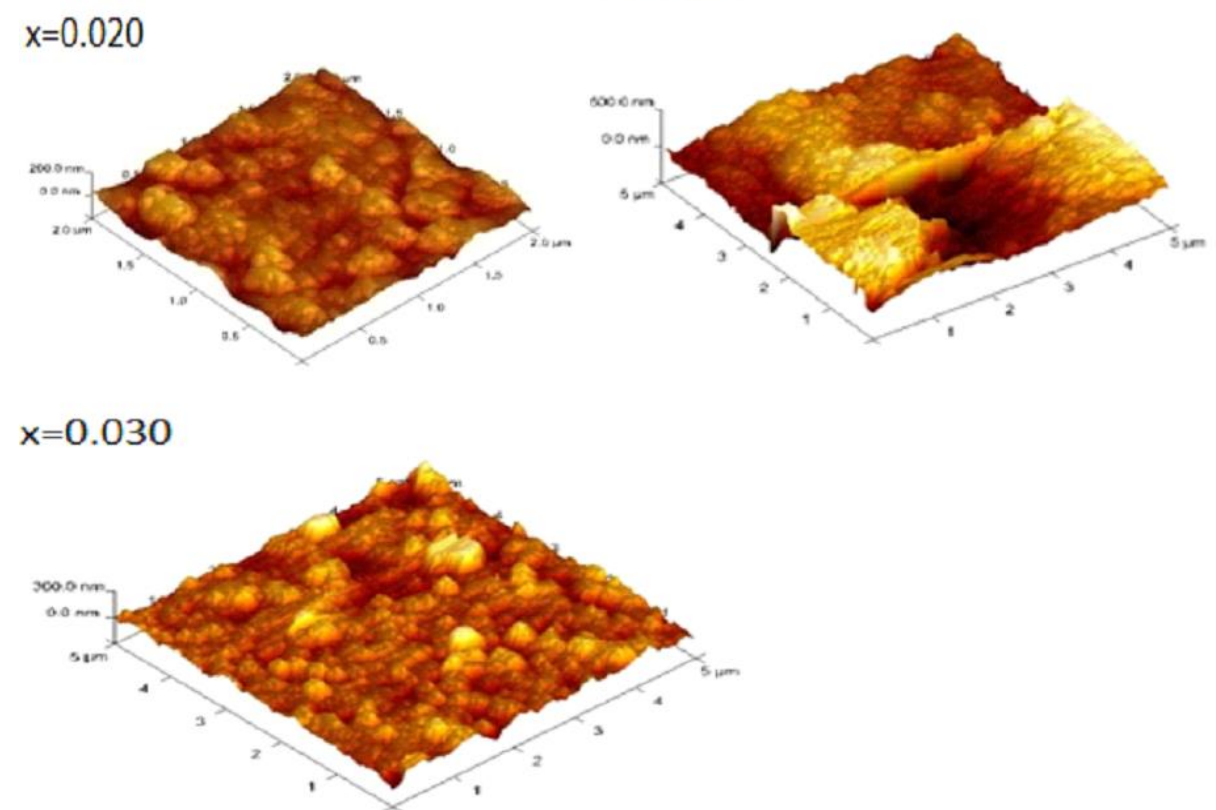

Figure 7. $\mathrm{AFM}$ micrographs of $\mathrm{CoFe}_{2} \mathrm{O}_{4}(\mathrm{x}=0.000)$ and $\mathrm{CoEr}_{\mathrm{x}} \mathrm{Fe}_{2-\mathrm{x}} \mathrm{O}_{4}(\mathrm{x}=0.005$ to 0.030$)$.

\subsection{TEM Analysis.}

The phase structure and morphology studies for the investigating synthesized samples were taken up through TEM analysis. Figure 8. shows the TEM images and their respective SAED images with particle size distribution chart of the samples got $\mathrm{x}=0.0,0.005,0.01,0.015$, $0.02,0.025$ and 0.03 respectively. TEM and SAED images demonstrated spherical shape and less thickness for most nanoparticles and few elongated particles. Observation of TEM images confirms well-distanced particles for lower concentrations of Er+3 ions and an increase in $\mathrm{Er}^{+3}$ ion substitution leads to agglomeration of particles because of magnetic nanoparticle interaction, which makes the particles be stacked on top of each other. The particle size measured from TEM images is in the range $16-24 \mathrm{~nm}$. 


\subsection{FTIR Analysis.}

FTIR (Fourier-Transform Infrared) spectroscopy is a very useful technique that estimates cationic redistribution at A and B sites of spinel ferrites. FTIR spectra for samples between $400 \mathrm{~cm}^{-1}$ and $1000 \mathrm{~cm}^{-1}$ was displayed by Figure 11 in which two important broad bands ( 1 in the range $500 \mathrm{~cm}^{-1}-600 \mathrm{~cm}^{-1}$ and 2 in the range $400 \mathrm{~cm}^{-1}-500 \mathrm{~cm}^{-1}$ ) were observed. As per Waldron's suggestion, intrinsic vibrations of $\mathrm{M}-\mathrm{O}$ complexes were shown by band 1 at site $\mathrm{A}$ site and band 2 at site $\mathrm{B}$. This difference between 1 and 2 was because of variation in the bond length of $\mathrm{Fe}^{+3}-\mathrm{O}^{-2}$ at $\mathrm{A}, \mathrm{B}$ sites $[32,34]$.
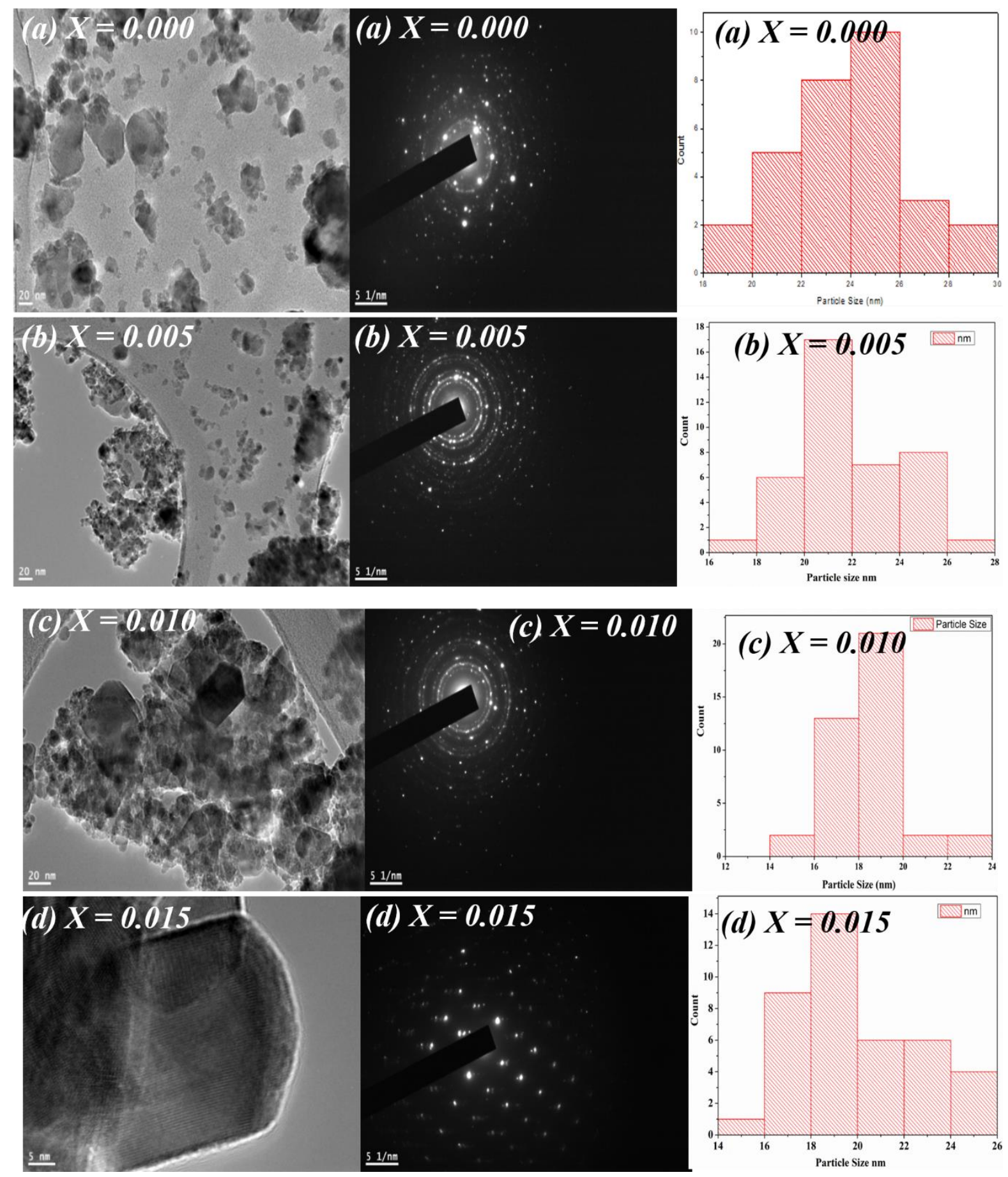

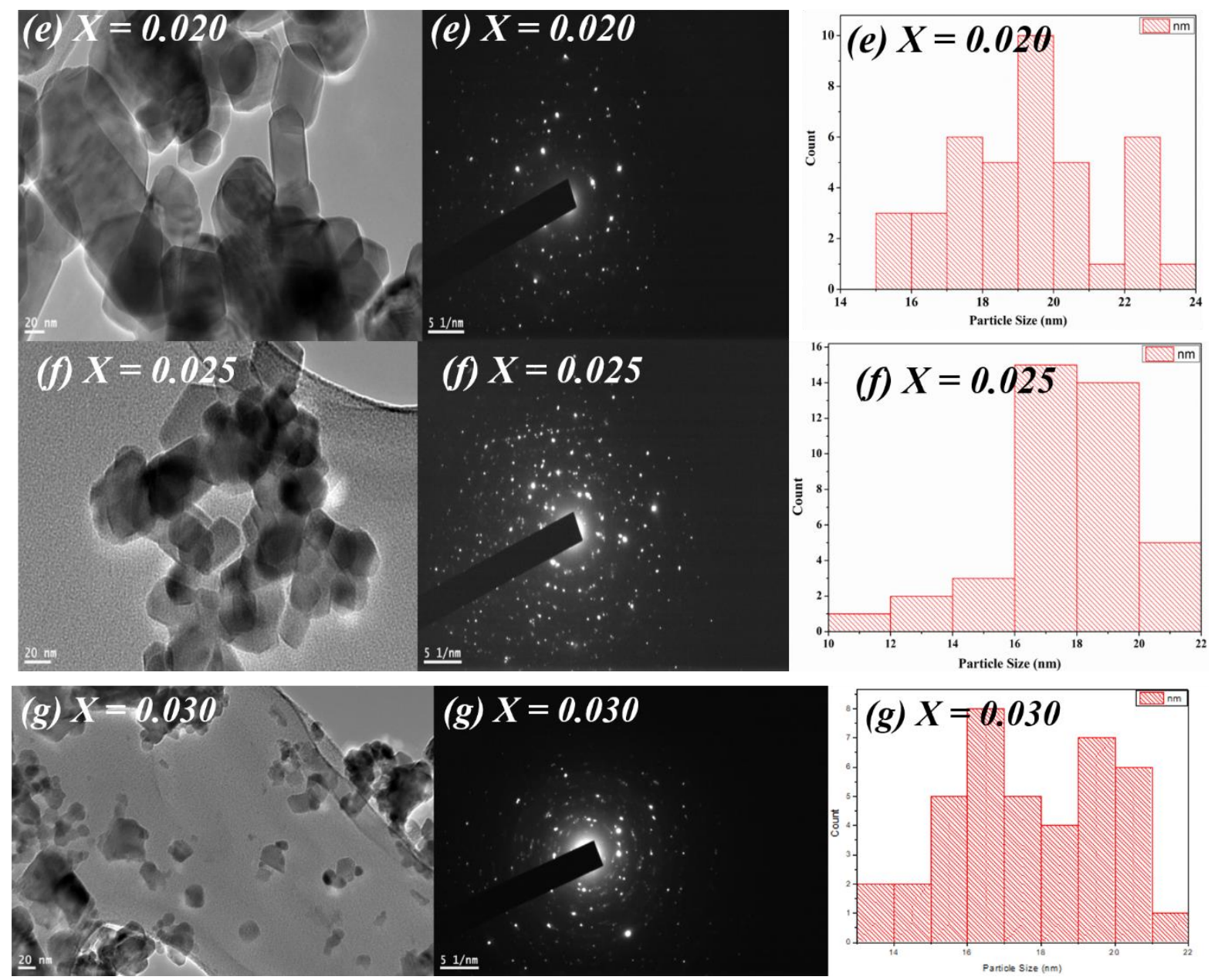

Figure 8(a-g). TEM, SAED, and histogram of particle size distribution micrographs (arranged horizontally) of $\mathrm{CoEr}_{\mathrm{x}} \mathrm{Fe}_{2-\mathrm{x}} \mathrm{O}_{4}$ ferrites with $\mathrm{x}=0.000$ to 0.030 respectively from (a) - (g).

Observations indicate a shift in octahedral (2) and tetrahedral (1) bands toward higher frequency with the addition of $\mathrm{Er}^{+3}$ ions due to bond length variation, expansion in $\mathrm{A}, \mathrm{B}$ sites, and cation migration between two sites. The residency of $\mathrm{Er}^{+3}$ ions at the B-site was also confirmed. FT-IR spectra of $\mathrm{CoFe}_{2} \mathrm{O}_{4}(\mathrm{x}=0.00)$ and $\mathrm{CoEr}_{\mathrm{x}} \mathrm{Fe}_{2-\mathrm{x}} \mathrm{O}_{4} \quad(\mathrm{x}=0.005$ to 0.030$)$ nanoparticles are shown in Figure 11. The values of force constant at tetrahedral and octahedral (Ft \& Fo) sites were determined using the formulas below [32], whose values are listed in Table 6.

$$
\begin{aligned}
& F t=4 \pi^{2} c^{2} v_{1}^{2} u \\
& F o=4 \pi^{2} c^{2} v_{2}^{2} u
\end{aligned}
$$

where vibrational frequencies of $\mathrm{A}, \mathrm{B}$ sites are denoted by $\mathrm{v}_{1}$, v2, reduced mass of $\mathrm{Fe}^{3+}$ and $\mathrm{O}^{2-}$ ions is $\mathrm{u}$, speed of light $=\mathrm{c}$.

Table 6. FTIR modes ( 1 and v2) and force constants $\left(\mathrm{F}_{\mathrm{T}}\right.$ and $\mathrm{F}_{\mathrm{o}}$ ) for Erbium substituted $\mathrm{CoEr}_{\mathrm{x}} \mathrm{Fe}_{2-\mathrm{x}} \mathrm{O}_{4}$

\begin{tabular}{c|c|c|c|c} 
Compositions & $\begin{array}{c}\text { Wave number } \\
\mathbf{V}_{\mathbf{1}}\left(\mathbf{c m}^{-\mathbf{1}}\right)\end{array}$ & $\begin{array}{c}\text { Wave number } \\
\mathbf{V}_{\mathbf{2}}\left(\mathbf{c m}^{-\mathbf{1}}\right)\end{array}$ & $\begin{array}{c}\mathbf{F}_{\mathbf{T}} \times \mathbf{1 0 5} \\
\mathbf{d y n e s} / \mathbf{c m})\end{array}$ & $\begin{array}{c}\mathbf{F}_{\mathbf{o}} \times \mathbf{1 0 5} \\
(\mathbf{d y n e s} / \mathbf{c m})\end{array}$ \\
\hline $\mathrm{CoFe}_{2} \mathrm{O}_{4}$ & 548 & 488 & 2.18 & 1.72 \\
\hline $\mathrm{CoEr}_{0.005} \mathrm{Fe}_{1.995} \mathrm{O}_{4}$ & 550 & 490 & 2.20 & 1.74 \\
\hline $\mathrm{CoEr}_{0.010} \mathrm{Fe}_{1.990} \mathrm{O}_{4}$ & 556 & 492 & 2.25 & 1.76 \\
\hline $\mathrm{CoEr}_{0.015} \mathrm{Fe}_{1.985} \mathrm{O}_{4}$ & 564 & 494 & 2.31 & 1.77 \\
\hline $\mathrm{CoEr}_{0.020} \mathrm{Fe}_{1.980} \mathrm{O}_{4}$ & 570 & 495 & 2.36 & 1.78 \\
\hline $\mathrm{CoEr}_{0.025} \mathrm{Fe}_{1.975} \mathrm{O}_{4}$ & 572 & 496 & 2.38 & 1.79 \\
\hline $\mathrm{CoEr}_{0.030} \mathrm{Fe}_{1.970} \mathrm{O}_{4}$ & 570 & 498 & 2.36 & 1.80
\end{tabular}




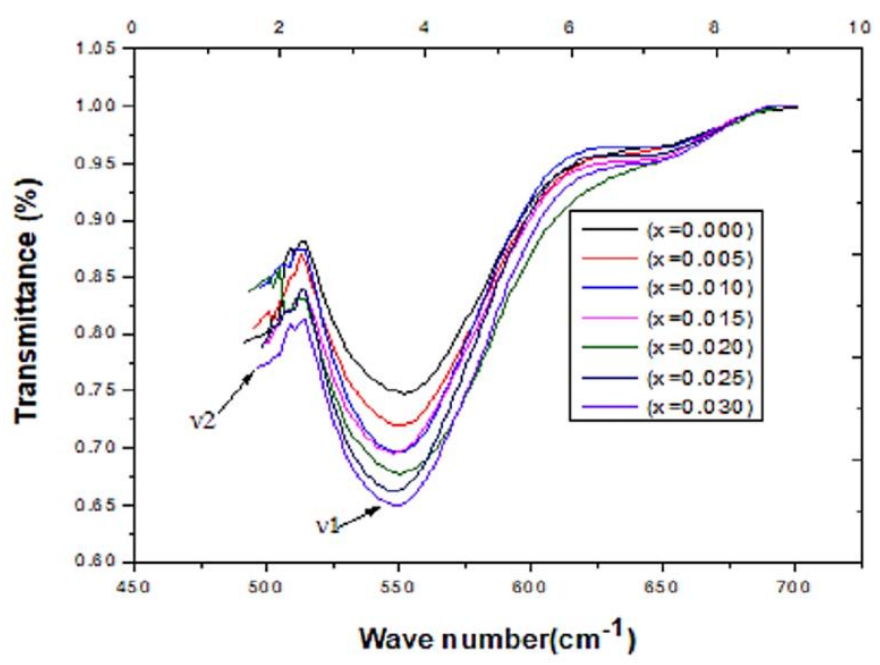

Figure 9. A variation of transmittance with wave number $\mathrm{CoEr}_{\mathrm{x}} \mathrm{Fe}_{2-\mathrm{x}} \mathrm{O}_{4}(\mathrm{x}=0.00-0.030)$ nano ferrites.

\subsection{Magnetic properties analysis.}

M-H curves (Hysteresis Loops) are plots drawn between magnetization (M) and applied field $(\mathrm{H})$, which helps us in analyzing magnetic response and magnetic parameters $[35,36]$ of ferrites under investigation. The $\mathrm{M}-\mathrm{H}$ loops of all nanoparticles, $\mathrm{CoEr}_{\mathrm{x}} \mathrm{Fe}_{2-\mathrm{x}} \mathrm{O}_{4}(\mathrm{x}=0.00-0.030)$, are heated at $500{ }^{\circ} \mathrm{C}$ are displayed in Figure 10. The measured magnetic parameters are displayed in Table 7. The Magnetic parameters such as Saturation magnetization (Ms), Remanent magnetization (Mr), Coercivity $(\mathrm{Hc})$ and Squareness ratio ( $\mathrm{R}=\mathrm{Mr} / \mathrm{Ms}$ ), Magnetic moment $\left(\mathrm{n}_{\mathrm{B}}\right)$ were altered by doping of $\mathrm{Er}^{+3}$ content in the increasing order ( $\mathrm{x}=0.00$ to 0.030$)$. Generally, dopant type, concentration, and morphology affect the magnetic properties of soft ferrite samples. Simultaneously, variation in magnetic parameters was seen due to microstructure noting higher saturation magnetization with larger grain size $[37,38]$. Table 7 indicate high saturation magnetization [39] and coercivity due to large grain size in $\mathrm{CoFe}_{2} \mathrm{O}_{4}$ ferrites as depicted by the hysteresis loop.

Ms value decreased from $60 \mathrm{emu} / \mathrm{g}$ to $44 \mathrm{emu} / \mathrm{g}$ with a decrease in grain size due to increased Er content in cobalt ferrite, which may be due to increased erbium cations in the ferrite lattice site [40]. Particularly, high magnetic moment $(5 \mu \mathrm{B})$ ferrite cations were replaced by erbium cations of the magnetic moment $7 \mu \mathrm{B}$ [10] at $\mathrm{B}$ sites. Besides, increasing erbium cations may decrease the ratio of ferric and ferrous ions at A, B sites, thereby decreasing the magnetic exchange interaction between two sites [41], reducing the Ms value. It was also observed that an increase of erbium content reduced the value of Hc from 18998 to 18990 Oe initiating the fact that magnetic moment can be changed with a low coercive field.

Hence coercivity variation is in agreement with variation in the anisotropy constant. Henceforth, the value of anisotropy constant 'K'decreases further, which decreases the energy of the magnetic domain wall. Remanent magnetization values decreased from $31 \mathrm{emu} / \mathrm{g}$ to 22 emu/g [42] system supporting soft magnetic nature due to low coercivity in erbium-doped cobalt ferrites [40]. 

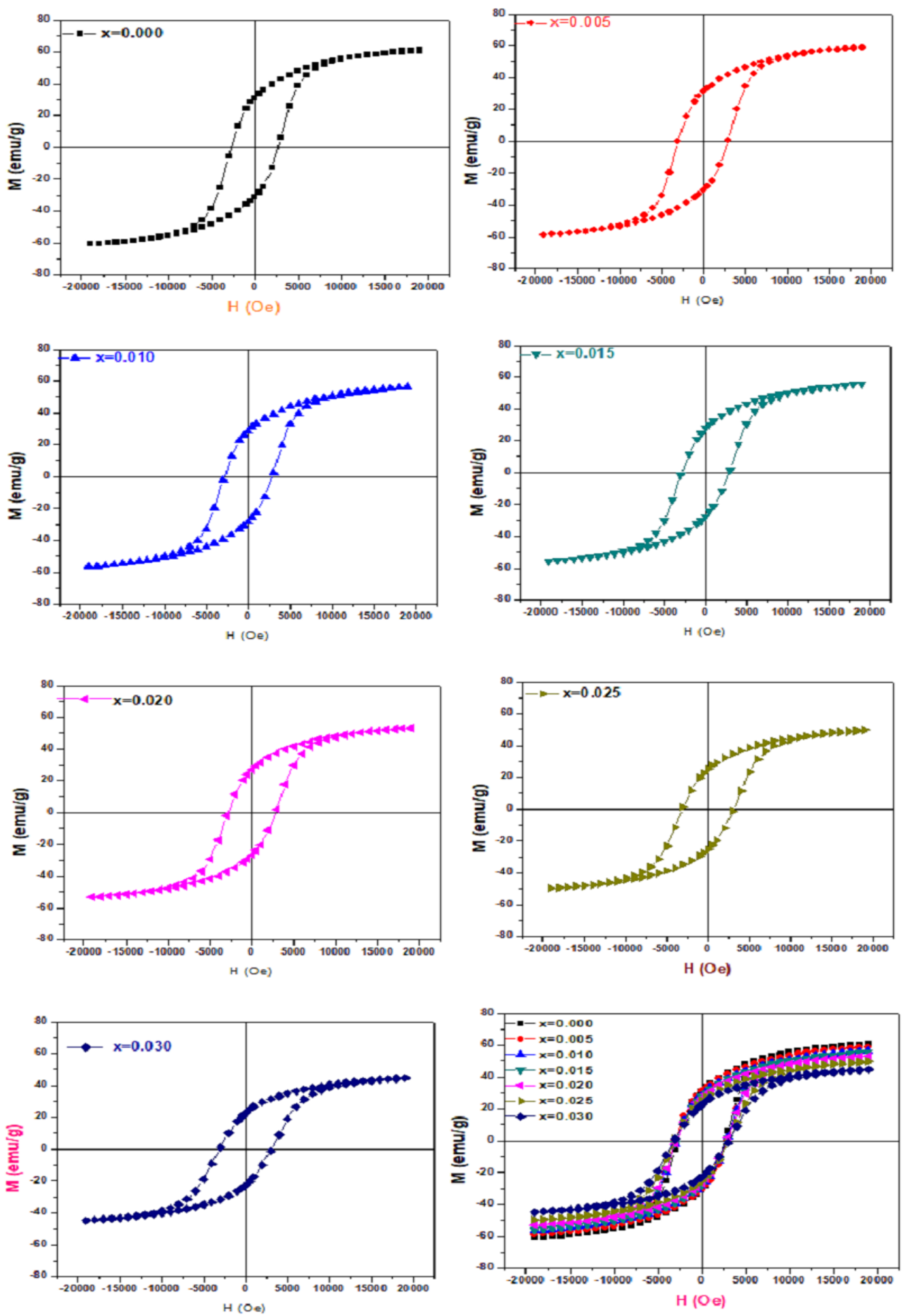

Figure 10. Magnetic hysteresis (M-H loops) curves of $\mathrm{CoEr}_{\mathrm{x}} \mathrm{Fe}_{2-\mathrm{x}} \mathrm{O}_{4}(\mathrm{x}=0.00-0.030)$ nano ferrites.

Table 7. The magnetic parameters for Erbium substituted $\mathrm{CoFe}_{2} \mathrm{O}_{4}$ nanoparticles.

\begin{tabular}{c|c|c|c|c|c|c|c|c} 
Composition & $\begin{array}{c}\text { Lattice } \\
\text { Parameter } \\
(\mathbf{a})\end{array}$ & $\begin{array}{c}\text { Crystallite } \\
\text { Size } \\
(\mathbf{n m})\end{array}$ & $\mathbf{H c}(\mathbf{c})$ & $\begin{array}{c}\mathbf{M s} \\
(\mathbf{e m u} / \mathbf{g})\end{array}$ & $\begin{array}{c}\mathbf{M r} \\
(\mathbf{e m u} / \mathbf{g})\end{array}$ & $\begin{array}{c}\mathbf{R}= \\
\mathbf{M r} / \mathbf{M s}\end{array}$ & $\mathbf{K}(\mathbf{e r g} / \mathbf{O e})$ & $\begin{array}{c}\text { Magnetic } \\
\text { moment } \\
(\boldsymbol{\mu} \mathbf{B} / \mathbf{f . u})\end{array}$ \\
\hline $\mathrm{CoFe}_{2} \mathrm{O}_{4}$ & 8.361 & 20.84 & 2998 & 60.6739 & 31.19 & 0.5141 & $188,479.783$ & 2.5488 \\
\hline $\mathrm{CoEr}_{0.005} \mathrm{Fe}_{1.995} \mathrm{O}_{4}$ & 8.392 & 20.43 & 2997 & 58.7486 & 31.07 & 0.5289 & $183,405.941$ & 2.4738 \\
\hline $\mathrm{CoEr}_{0.010} \mathrm{Fe}_{1.990} \mathrm{O}_{4}$ & 8.407 & 19.19 & 2996 & 56.9560 & 28.86 & 0.5067 & $177,750.433$ & 2.4040 \\
\hline $\mathrm{CoEr}_{0.015} \mathrm{Fe}_{1.985} \mathrm{O}_{4}$ & 8.367 & 19.02 & 2995 & 55.4902 & 27.66 & 0.5136 & $173,117.863$ & 2.2784 \\
\hline $\mathrm{CoEr}_{0.020} \mathrm{Fe}_{1.980} \mathrm{O}_{4}$ & 8.367 & 17.73 & 2993 & 53.1555 & 26.83 & 0.5208 & $165,723.033$ & 2.1853 \\
\hline $\mathrm{CoEr}_{0.025} \mathrm{Fe}_{1.975} \mathrm{O}_{4}$ & 8.386 & 15.56 & 2991 & 49.5845 & 25.15 & 0.5240 & $154,486.957$ & 2.0400 \\
\hline $\mathrm{CoEr}_{0.030} \mathrm{Fe}_{1.970} \mathrm{O}_{4}$ & 8.398 & 14.4 & 2989 & 44.8444 & 22.88 & 0.5275 & $139,625.157$ & 1.8480
\end{tabular}


Table 7 indicates a decrease in the magnetic moment with increased erbium content which may be assigned to a more probable chance of erbium cations to occupy B sites. As per the revealed data, increasing erbium content decreases magnetization converting the sample into soft magnetic material. It is understood that an increase in erbium content decreases the value of ' $\mathrm{K}$ '. $\mathrm{M}-\mathrm{H}$ loops indicated that soft magnetic Co-Er nano ferrites could be easily magnetized and demagnetized. Squareness ratio $(\mathrm{R}=\mathrm{Mr} / \mathrm{Ms})$ was estimated from

$$
\mathrm{R}=\frac{\mathrm{M}_{\mathrm{r}}}{\mathrm{M}_{\mathrm{S}}}
$$

where $\mathrm{M}_{\mathrm{r}}$ is remanent magnetization, $\mathrm{M}_{\mathrm{s}}$ is the saturation magnetization.

The magnetic moment per unit $(\eta \mathrm{B})$ was calculated from $[34,43]$ :

$$
n_{B}=\frac{M_{\omega} \times M_{S}}{5585}
$$

where $\mathrm{M} \omega$ and $\mathrm{Ms}$ are samples molecular weight and saturation magnetization

$\mathrm{K}$ (magnetic anisotropic constant) is related to the Ms (saturation magnetization) and $\mathrm{Hc}$ (magnetic coercivity) [28] by the following relation:

$$
k=\frac{M s \times H c}{0.96}
$$

\section{Conclusion}

Synthesis and characterization of erbium substituted cobalt ferrites and conglomeration were done using the citrate-gel auto combustion method. A significant induced effect of erbium was observed on the crystal structure, morphology, and magnetic properties of cobalt ferrite material. Copy of secondary $\mathrm{ErFeO}_{3}$ and primary spinel cubic structure occurs only for Ercontent, $x=0.015,0.020$, and regains its primary spinal structure for Er content $\mathrm{x}=0.025$, 0.030 while the crystallite size decreased from $20.84 \mathrm{~nm}-14.40 \mathrm{~nm}$. According to the SEM analysis, the growth in grain and agglomeration form were found for all samples. Observations indicated strong dependence of magnetic properties on Erbium substitution, and coercivity varies per anisotropy constant. The presence of magnetic dipole could be useful for considering the erbium substituted cobalt ferrites in electromagnetic applications. The studies of $\mathrm{CoEr}_{x} \mathrm{Fe}_{2}-$ $\mathrm{x}_{4}$ for compositions with cobalt content $\mathrm{x}=0.0$ to 0.030 with increasing order of $\mathrm{x}=0.005$ indicated decreasing crystallite size with increasing erbium content and increase in surface area of the particle makes it a promising adsorbent. Hence these adsorbents can be used in gas sensors and wastewater treatment.

\section{Funding}

This research received no external funding from any organization.

\section{Acknowledgments}

Thanks to CSIR, New Delhi, India for Research Fellowship (CSIR-JRF). The authors are grateful to Prof. Syed Rahman, Head Department of Physics, University College of Science, Osmania University Hyderabad, for his constant encouragement. 


\section{Conflicts of Interest}

The authors declare no conflict of interest.

\section{References}

1. Habib, A.H.; Ondeck, C.L.; Chaudhary, P.; Bockstaller, M.R.; McHenry, M.E. Evaluation of ironcobalt/ferrite core-shell nanoparticles for cancer thermotherapy. J. Appl. Phys. 2008, 103, 07A307, https://doi.org/10.1063/1.2830975.

2. V. L. Ene, I. A. Neacsu, O. Oprea, V. A. Surdu, R. D. Trusca, A. Ficai, and E. Andronescu, "Single Step Synthesis of Glutamic/tartaric Acid-stabilised Fe3O4 Nanoparticles for Targeted Delivery Systems" Revista de Chimie 2020, 71, 230-238, https://doi.org/10.37358/rc.20.2.7920.

3. Song, Q.; Zhang, Z.J. Shape Control and Associated Magnetic Properties of Spinel Cobalt Ferrite Nanocrystals. J. Am. Chem. Soc. 2004, 126, 6164-6168, https://doi.org/10.1021/ja049931r.

4. Annie Vinosha, P.; Jerome Das, S. Investigation on the role of $\mathrm{pH}$ for the structural, optical and magnetic properties of cobalt ferrite nanoparticles and its effect on the photo-fenton activity. Materials Today: Proceedings 2018, 5, 8662-8671, https://doi.org/10.1016/j.matpr.2017.12.291.

5. Vázquez-Vázquez, C.; Lovelle, M.; Mateo, C.; López-Quintela, M.A.; Buján-Núñez, M.C.; Serantes, D.; Baldomir, D.; Rivas, J. Magnetocaloric effect and size-dependent study of the magnetic properties of cobalt ferrite nanoparticles prepared by solvothermal synthesis. physica status solidi (a) 2008, 205, 1358-1362, https://doi.org/10.1002/pssa.200778128.

6. Nlebedim, I.C.; Hadimani, R.L.; Prozorov, R.; Jiles, D.C. Structural, magnetic, and magnetoelastic properties of magnesium substituted cobalt ferrite. J. Appl. Phys. 2013, 113, 17A928,https://doi.org/10.1063/1.4798822.

7. Feng, A.; Hou, T.; Jia, Z.; Wu, G. Synthesis of a hierarchical carbon fiber@ cobalt ferrite@ manganese dioxide composite and its application as a microwave absorber. RSC Advances 2020, 10, 10510-10518, https://doi.org/10.1039/C9RA10327A.

8. Prathapani, S.; Jayaraman, T.V.; Varaprasadarao, E.K.; Das, D. Structural and ambient/sub-ambient temperature magnetic properties of Er-substituted cobalt-ferrites synthesized by sol-gel assisted autocombustion method. J. Appl. Phys. 2014, 116, 023908,https://doi.org/10.1063/1.4889929.

9. Cullity,B.D.; Graham,C.D. Introduction to Magnetic Materials, 2nd Edition. Wiley-IEEE Press; 2008, https://doi.org/10.1002/9780470386323.

10. Weiss,A. Magnetic Oxides, Parts 1 and 2. John Wiley \& Sons, Bristol, 1975, https://doi.org/10.1002/bbpc.19760800218.

11. Tatarchuk, T.; Mironyuk, I.; Kotsyubynsky, V.; Shyichuk, A.; Myslin, M.; Boychuk, V. Structure, morphology and adsorption properties of titania shell immobilized onto cobalt ferrite nanoparticle core. $J$. Mol. Liq. 2020, 297, 111757, https://doi.org/10.1016/j.molliq.2019.111757.

12. Heiba, Z.K.; Bakr Mohamed, M.; Arda, L.; Dogan, N. Cation distribution correlated with magnetic properties of nanocrystalline gadolinium substituted nickel ferrite. J. Magn. Magn. Mater. 2015, 391, 195202,https://doi.org/10.1016/j.jmmm.2015.05.003.

13. Kambale, R.C.; Shaikh, P.A.; Kamble, S.S.; Kolekar, Y.D. Effect of cobalt substitution on structural, magnetic and electric properties of nickel ferrite. J. Alloys Compd. 2009, 478, 599-603, https://doi.org/10.1016/j.jallcom.2008.11.101.

14. Kamran, M.; Anis-ur-Rehman, M. Enhanced transport properties in Ce doped cobalt ferrites nanoparticles for resistive RAM applications. J. Alloys Compd. 2020, 822, 153583, doi:https://doi.org/10.1016/j.jallcom.2019.153583

15. Dobrott, R.D. X-ray Diffraction Methods, In: Kane P.F., Larrabee G. B. (eds) Characterization of Solid Surfaces 1974, 147-178, Springer, Boston, MA, https://doi.org/10.1007/978-1-4613-4490-2_8.

16. Andreu, I.; Natividad, E.; Ravagli, C.; Castro, M.; Baldi, G. Heating ability of cobalt ferrite nanoparticles showing dynamic and interaction effects. RSC Advances 2014, 4, 28968-28977, https://doi.org/10.1039/C4RA02586E.

17. Kakade, S.G.; Ma, Y.-R.; Devan, R.S.; Kolekar, Y.D.; Ramana, C.V. Dielectric, Complex Impedance, and Electrical Transport Properties of Erbium (Er3+) Ion-Substituted Nanocrystalline, Cobalt-Rich Ferrite (Co1.1Fe1.9-xErxO4). The Journal of Physical Chemistry $C$ 2016, 120, 5682-5693, https://doi.org/10.1021/acs.jpcc.5b11188. 
18. Park, K.; Hwang, H.K. Fabrication and electrical properties of nanocrystalline Dy3+-doped CeO2 for intermediate-temperature solid oxide fuel cells. Energy 2013, 55, 304-309, https://doi.org/10.1016/j.energy.2013.04.017

19. Kumari, N.; Kour, S.; Singh, G.; Sharma, R.K. A brief review on synthesis, properties and applications of ferrites. AIP Conf. Proc. 2020, 2220, 020164, https://doi.org/10.1063/5.0001323.

20. Hashim, M.; Alimuddin; Kumar, S.; Shirsath, S.E.; Kotnala, R.K.; Shah, J.; Kumar, R. Synthesis and characterizations of Ni2+ substituted cobalt ferrite nanoparticles. Mater. Chem. Phys. 2013, 139, 364-374, https://doi.org/10.1016/j.matchemphys.2012.09.019.

21. Ahsan, M.Z.; Islam, M.A.; Bally, A.A.; Khan, F.A. Spectroscopic analysis for electric and magnetic properties of manganese doped cobalt nanoferrite. Results in Physics 2020, 17, 103172, https://doi.org/10.1016/j.rinp.2020.103172.

22. Chen, X.; Wang, W.; Shi, T.; Wu, G.; Lu, Y. One pot green synthesis and EM wave absorption performance of MoS2@ nitrogen doped carbon hybrid decorated with ultrasmall cobalt ferrite nanoparticles. Carbon 2020, 163, 202-212, https://doi.org/10.1016/j.carbon.2020.03.005.

23. Wu, Y.; Li, J.; Bai, H.; He, S.; Hong, Y.; Shi, K.; Zhou, Z. Colossal Dielectric Behavior and Dielectric Relaxation of (Li, Fe) Co-Doped ZnO Ceramics. physica status solidi (RRL) - Rapid Research Letters 2018, 12, 1800126, https://doi.org/10.1002/pssr.201800126.

24. Salunkhe, A.B.; Khot, V.M.; Phadatare, M.R.; Thorat, N.D.; Joshi, R.S.; Yadav, H.M.; Pawar, S.H. Low temperature combustion synthesis and magnetostructural properties of Co-Mn nanoferrites. J. Magn. Magn. Mater. 2014, 352, 91-98, https://doi.org/10.1016/j.jmmm.2013.09.020.

25. Rus,S.F.; Vlazan,P.; Herklotz,A. Synthesis and characterization of Zirconium substituted cobalt ferrite nanopowders. Journal of Nanoscience and Nanotechnology 2016, 16, 1 , https://www.osti.gov/pages/servlets/purl/1324165.

26. Rathore, D.; Kurchania, R.; Pandey, R.K. Influence of particle size and temperature on the dielectric properties of $\mathrm{CoFe} 2 \mathrm{O} 4$ nanoparticles. International Journal of Minerals, Metallurgy, and Materials 2014, 21, 408-414, https://doi.org/10.1007/s12613-014-0923-8.

27. Moon, K.-S.; Lim, E.-S.; Kang, Y.-M. Effect of Ca and La substitution on the structure and magnetic properties of M-type Sr-hexaferrites. J. Alloys Compd. 2019, 771, 350-355, https://doi.org/10.1016/j.jallcom.2018.08.306.

28. Goldman,A. Modern Ferrite Technology, 2nd ed. Ferrite Technology Pittsburgh, PA, USA, 2006. Available online: https://download.e-bookshelf.de/download/0000/0009/50/L-G-0000000950-0002340313.pdf.

29. Raghasudha, M.; Ravinder, D.; Veerasomaiah, P. FTIR Studies and Dielectric Properties of Cr Substituted Cobalt Nano Ferrites Synthesized by Citrate-Gel Method. Nanoscience and Nanotechnology 2013, 3, 105114, https://doi.org/10.5923/j.nn.20130305.01.

30. Kurlyandskaya, G.V.; Bhagat, S.M.; Jacobo, S.E.; Aphesteguy, J.C.; Schegoleva, N.N. Microwave resonant and zero-field absorption study of pure and doped ferrite nanoparticles. J. Phys. Chem. Solids 2011, 72, 276285, https://doi.org/10.1016/j.jpcs.2011.01.002.

31. Majid, F.; Nazir, A.; Ata, S.; Bibi, I.; Mehmood, H.S.; Malik, A.; Ali, A.; Iqbal, M. Effect of Hydrothermal Reaction Time on Electrical, Structural and Magnetic Properties of Cobalt Ferrite. Z. Phys. Chem. 2020, 234, 323-353, https://doi.org/10.1515/zpch-2019-1423.

32. Mazen, S.A.; Abu-Elsaad, N.I. IR Spectra, Elastic and Dielectric Properties of Li-Mn Ferrite. ISRN Condensed Matter Physics 2012, 2012, 907257, https://doi.org/10.5402/2012/907257.

33. Kumar, H.; Singh, J.P.; Srivastava, R.C.; Negi, P.; Agrawal, H.M.; Asokan, K. FTIR and Electrical Study of Dysprosium Doped Cobalt Ferrite Nanoparticles. Journal of Nanoscience 2014, 2014, 862415, https://doi.org/10.1155/2014/862415.

34. Pradeep, A.; Priyadharsini, P.; Chandrasekaran, G. Sol-gel route of synthesis of nanoparticles of MgFe2O4 and XRD, FTIR and VSM study. J. Magn. Magn. Mater. 2008, 320, 2774-2779, https://doi.org/10.1016/j.jmmm.2008.06.012.

35. Andhare, D.D.; Patade, S.R.; Kounsalye, J.S.; Jadhav, K.M. Effect of Zn doping on structural, magnetic and optical properties of cobalt ferrite nanoparticles synthesized via. Co-precipitation method. Physica B: Condensed Matter 2020, 583, 412051, https://doi.org/10.1016/j.physb.2020.412051.

36. Shyamaldas; Bououdina, M.; Manoharan, C. Dependence of structure/morphology on electrical/magnetic properties of hydrothermally synthesised cobalt ferrite nanoparticles. J. Magn. Magn. Mater. 2020, 493, 165703, https://doi.org/10.1016/j.jmmm.2019.165703. 
37. Hashim, M.; Ahmed, A.; Ali, S.A.; Shirsath, S.E.; Ismail, M.M.; Kumar, R.; Kumar, S.; Meena, S.S.; Ravinder, D. Structural, optical, elastic and magnetic properties of Ce and Dy doped cobalt ferrites. J. Alloys Compd. 2020, 834, 155089, https://doi.org/10.1016/j.jallcom.2020.155089.

38. Ateia, E.E.; Abdelmaksoud, M.K.; Arman, M.M.; Shafaay, A.S. Comparative study on the physical properties of rare-earth-substituted nano-sized CoFe2O4. Appl. Phys. A 2020, 126, 91, https://doi.org/10.1007/s00339020-3282-5.

39. Mammo, T.W.; Murali, N.; Kumari, C.V.; Margarette, S.J.; Ramakrishna, A.; Vemuri, R.; Shankar Rao, Y.B.; Vijaya Prasad, K.L.; Ramakrishna, Y.; Samatha, K. Synthesis, structural, dielectric and magnetic properties of cobalt ferrite nanomaterial prepared by sol-gel autocombustion technique. Physica B: Condensed Matter 2020, 581, 411769, https://doi.org/10.1016/j.physb.2019.411769.

40. Nag, S.; Roychowdhury, A.; Das, D.; Das, S.; Mukherjee, S. Structural and magnetic properties of erbium (Er3+) doped nickel zinc ferrite prepared by sol-gel auto-combustion method. J. Magn. Magn. Mater. 2018, 466, 172-179, https://doi.org/10.1016/j.jmmm.2018.06.084.

41. Gaffoor, A.; Naidu, K.C.B.; Ravinder, D.; Batoo, K.M.; Adil, S.F.; Khan, M. Synthesis of nano-NiXFe2O4 $(\mathrm{X}=\mathrm{Mg} / \mathrm{Co})$ by citrate-gel method: structural, morphological and low-temperature magnetic properties. Appl. Phys. A 2019, 126, 39, https://doi.org/10.1007/s00339-019-3225-1.

42. Dou, R.; Cheng, H.; Ma, J.; Komarneni, S. Manganese doped magnetic cobalt ferrite nanoparticles for dye degradation via a novel heterogeneous chemical catalysis. Mater. Chem. Phys. 2020, 240, 122181, https://doi.org/10.1016/j.matchemphys.2019.122181.

43. Ajeesha, T.L.; Anantharaman, A.; Baby, J.N.; George, M. Structural, Magnetic, Electrical and Photo-Fenton Properties of Copper Substituted Strontium M-Hexagonal Ferrite Nanomaterials via Chemical Coprecipitation Approach. Journal of Nanoscience and Nanotechnology 2020, 20, 1589-1604. https://doi.org/10.1166/jnn.2020.17132. 